\title{
CONCENTRATION OF ORGANOCHLORINE PESTICIDES IN WATER AND BOTTOM SEDIMENTS OF THE DNIESTER RIVER ECOSYSTEM
}

\author{
Vladimir Ukrainskiy ${ }^{1}$, Svitlana Kovalyshyna ${ }^{1}$, Yuriy Denga ${ }^{1}$, \\ Anastasia Ivanova ${ }^{2}$, Nadejda Andreev², Elena Zubcov², Antoaneta Ene ${ }^{3}$ \\ ${ }^{1}$ SRI Ukrainian Scientific Center of Ecology of the Sea, Ukraine, \\ e-mail: svetakovalish@gmail.com; \\ ${ }^{2}$ Institute of Zoology, Chisinau, Moldova, e-mail: ivanova89md@gmail.com; \\ ${ }^{3}$ University Dunarea de Jos, Galati, Romania, e-mail: antoaneta.ene@ugal.ro
}

\begin{abstract}
The main goal of this study is assessing the degree of water and bottom sediment pollution in the lower Dniester by organochlorine pesticides. During the study period, the waters of the lower Dniester were in satisfactory state, an excess of EQS was registered only for the $\gamma$-isomer of HCH (Lindane), for other pollutants, an excess of EQS was not noted. The main pollutants were accumulated in bottom sediments, which is associated with the input of organic matter, bio-sedimentation. The concentration of $\gamma$-isomer HCH (lindane) in bottom sediments exceeded EQS by 5 and 20 times in spring and summer, respectively, DDT exceeded EQS by more than 4 times in summer, POPs (dieldrin and heptachlor) in summer exceeded EQS by 10.8 and 2.5 times, respectively.
\end{abstract}

\section{Introduction}

State assessment and variability of water and bottom sediment pollution by toxic substances and pollutants in the lower Dniester is an important indicator of the integral transboundary load from the entire basin on the ecosystems of the lower part of the river, the Dniester estuary and the adjacent Black Sea coastal area. Therefore, the main goal of this study is assessing the degree of water and bottom sediment pollution in the lower Dniester by organochlorine pesticides according to the Water Framework Directive 2000/60/EC [1, 2]. In the lower Dniester, the most polluted part is between the cities of Dubossary and Bendery. Most pollutants come to this territory from the runoff of the Reut and Byk rivers, in which basins there are located the main large and medium industrial and communal enterprises of Moldova, together with majority of water users [3].

Ukrainian part of the lower Dniester, together with the transboundary transport of pollutants, is also affected by industrial and municipal enterprises of the Odessa region, as well as food industry enterprises. Irrigation systems are also a significant pollutant, the largest of which is the Dniester irrigation system with a high concentration of easily oxidizing organic substances in its waters.

\section{Materials and methods}

Water and bottom sediments were sampled in the lower Dniester under the project BSB165 HydroEcoNex, near the village Mayaki, at a distance of $15.4 \mathrm{~km}$ from the confluence of the Dniester river into the Dniester estuary. The present paper covers the period of study from December 2018 to August 2019.

To analyze the concentration of pollutants in bottom sediments, the samples were prelimi- 
narily dried in a vacuum freezer, homogenized, and weighed by the analytical weighing scales. Chlorinated hydrocarbons (OCPs) were analyzed by capillary gas chromatography, using an Agilent 7890B gas chromatograph with a capillary column and an electron capture detector according to the measurement procedure (MVI) No. 10/09-09 Sea waters approved by the State Enterprise "Odessa Regional Center for Standardization, Metrology and Certification". The certification was carried out according State Standard GOST 8.010-99.

\section{Results and discussion}

Organochlorine pesticides (OCPs) are a group of synthetic poisons created primarily for insect control. A number of organochlorine pesticides $(\alpha, \beta$ and $\gamma$ isomers of HCH, DDT and its metabolites DDE, DDD, aldrin, dieldrin, heptachlor, hexachlorobenzene, etc.) belong to the dangerous group of persistent organic pollutants (POPs). The most toxic OCPs are dichlorodiphenyltrichloroethane DDT and $\mathrm{HCH}$ (lindane), which were first by production and use in agriculture until the 1980s [4]. The widespread use of OCPs in agriculture and other industries in the last century led to their accumulation in environment, in water bodies and soils, and their migration along the food chains from lower to higher levels of the ecosystem. In aquatic ecosystems, take place a sorption of organochlorine compounds by suspensions, with subsequent sedimentation and burial in bottom sediments.

During the observation period, $\gamma$-isomer of $\mathrm{HCH}$ (lindane) was registered in all water samples. Its concentrations were in the range of 0.17-2.12 ng/1, and in February exceeded the ecological quality standard by more than 10 times $(\mathrm{EQS}=0.20 \mathrm{ng} / \mathrm{l})$. The lindane concentration averaged $0.60 \mathrm{ng} / \mathrm{l}$. Concentrations of the $\beta$-isomer of $\mathrm{HCH}$ varied from analytical zero $<0.05$ $\mathrm{ng} / \mathrm{l}$ to $1.55 \mathrm{ng} / \mathrm{l}$, the average value was $0.55 \mathrm{ng} / \mathrm{l}$. In all water samples, $\alpha-\mathrm{HCH}$ isomer was not detected.

The presence of DDT (dichlorodiphenyltrichloroethane) was observed in all water samples. Its concentration varied within the range of 3.15-17.95 ng/l and did not exceed the ecological quality standard $(\mathrm{EQS}=25.0 \mathrm{ng} / \mathrm{l})$. The average DDT concentration in the Dniester waters during the study period was $9.58 \mathrm{ng} / \mathrm{l}$. The presence of its transformation product DDE (dichlorodiphenyldichloroethene) was not observed. The presence of DDD (dichlorodiphenyldichloroethane) was observed in only three out of nine water samples with a maximum concentration of $1.97 \mathrm{ng} / \mathrm{l}$ in February. The total concentration of DDT and its metabolites was in the range of 3.28-19.42 ng/1 and did not exceed EQS. The average concentrations in water of lindane and the DDTsum (DDT + its transformation products) decreased in spring (April-May) (Fig. 1).

A decrease in the concentrations of $\mathrm{HCHg}$ and DDTsum in spring may be caused by their dilution due to increase of water runoff during the flood period.

In the lower Dniester waters, organochlorine compounds of POPs group (aldrin, dieldrin, heptachlor, hexachlorobenzene) were not detected during this observation period. 


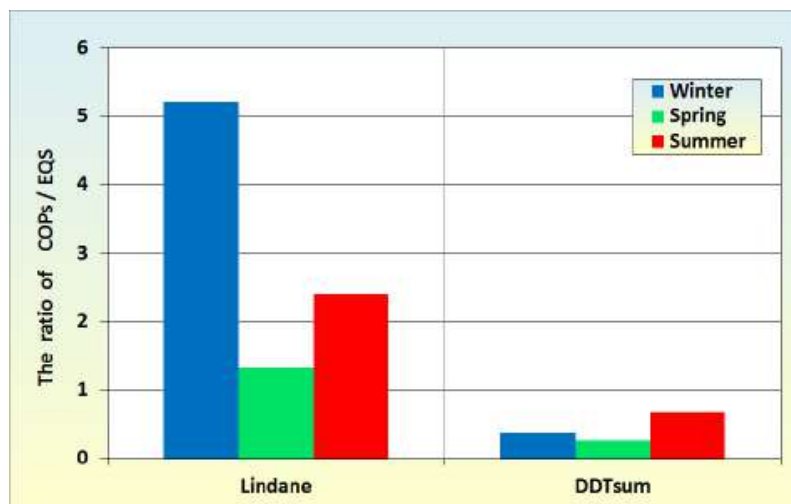

Figure 1. The ratio of OCPs concentration to their EQS (average per season) in the waters of lower Dniester in 2019

The transfer of organochlorine compounds to bottom sediments is largely due to biosedimentation - accumulation and sedimentation with suspended organic material. In bottom sediments in the lower Dniester, the concentration of the $\gamma$-isomer HCH (lindane) was $0.25 \mathrm{mkg} /$ $\mathrm{kg}$ in March, $1.02 \mathrm{mkg} / \mathrm{kg}$ in June, thus, exceeded the environmental quality standard by 5 and 20 times respectively (EQS $=0.05 \mathrm{mkg} / \mathrm{kg}$ ); $\beta$-isomer of $\mathrm{HCH}$ was noted only in March, with the concentration of $0.24 \mathrm{mkg} / \mathrm{kg} ; \alpha$-isomer of $\mathrm{HCH}$ was not detected in bottom sediments, the same as in water. It is noteworthy that earlier studies [5] of bottom sediments in the lower Dniester also revealed the presence of the $\beta$-isomer $\mathrm{HCH}$ in the samples in a similar concentration range from 0.04 to $0.28 \mathrm{mkg} / \mathrm{kg}$. The $\alpha-\mathrm{HCH}$ isomer was also detected in the samples of bottom sediments, the average concentrations varied from 0.05 to $0.059 \mathrm{mkg} / \mathrm{kg}$.

The DDT (dichlorodiphenyltrichloroethane) concentration in bottom sediments in March was $1.52 \mathrm{mkg} / \mathrm{kg}$, and in June $10.90 \mathrm{mkg} / \mathrm{kg}$, exceeding more than 4 times the environmental quality standard (EQS $=2.5 \mathrm{mkg} / \mathrm{kg}$ ) (Fig. 2).

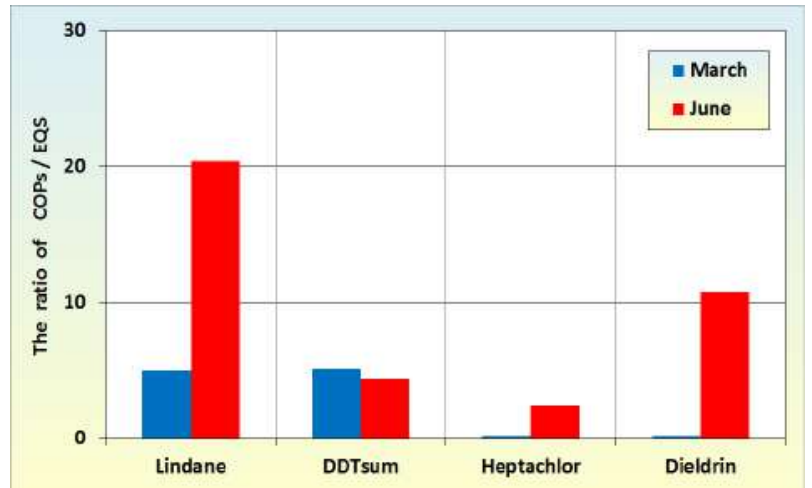

Figure 2. The ratio of OCPs concentration to their EQS in bottom sediments of lower Dniester in March and June 2019

In March, the presence of DDD (dichlorodiphenyldichloroethane) in the concentration of $9.68 \mathrm{mkg} / \mathrm{kg}$ was noted in the bottom sediments, which is almost 4 times higher than the EQS. 
DDE (dichlorodiphenyldichloroethene) was detected in the sediments in March at $1.59 \mathrm{mkg} /$ $\mathrm{kg}$. In previous studies of bottom sediments in the Moldavian part of the lower Dniester from Vadul-lui-Voda to Palanca, the concentrations of DDT and its transformation products DDD and DDE were several times lower than our data and amounted to $0.08,1.68$ and $1.14 \mathrm{mkg} / \mathrm{kg}$, respectively [6].

In general, our results were much higher than the total concentrations of DDT and HCH in bottom sediments established for the lower Dniester in 2017-2018, which averaged $7.9 \mathrm{mkg} / \mathrm{kg}$ and $0.19 \mathrm{mkg} / \mathrm{kg}$, respectively [5].

In bottom sediments, among the pesticides of POPs group (aldrin, dieldrin, heptachlor, hexachlorobenzene), dieldrin and heptachlor were detected in June at concentrations of $5.4 \mathrm{mkg} /$ $\mathrm{kg}$ and $6.13 \mathrm{mkg} / \mathrm{kg}$, respectively, with an excess of EQS of 10.8 and 2.5 times.

\section{Conclusions}

During the study period, the waters of the lower Dniester were in satisfactory state, an excess of EQS was registered only for the $\gamma$-isomer of HCH (Lindane), for other pollutants, an excess of EQS was not noted. The main pollutants were accumulated in bottom sediments, which is associated with the input of organic matter, bio-sedimentation. The concentration of $\gamma$-isomer $\mathrm{HCH}$ (lindane) in bottom sediments exceeded EQS by 5 and 20 times in spring and summer, respectively, DDT exceeded EQS by more than 4 times in summer, POPs (dieldrin and heptachlor) in summer exceeded EQS by 10.8 and 2.5 times, respectively.

Acknowledgements: We acknowledge the funding from ENI project with eMS code BSB165 HydroEcoNex (2018-2021), Joint Operational Programme Black Sea Basin 2014-2020.

\section{Bibliography}

1. Директива 2000/60/СС Свропейського Парламенту і Ради “Про встановлення рамок діяльності співтовариства в галузі водної політики" від 23 жовтня 2000 року [Электронный pecypc]. https://zakon.rada.gov.ua/go/994_962.

2. Vladimir Ukrainskiy, Yuriy Denga, Svetlana Kovalyshyna, Anastasia Ivanova, Elena Zubcov, Antoaneta Ene Organochlorine pesticides in water and bottom sediments of the Dniester River ecosystem. Abstracts of the International Conference "Environmental Toxicants in Freshwater and Marine Ecosystems in the Black Sea Basin", Kavala, Greece, September 8-11, 2020, p.2628

3. Загрязнение воды в бассейне Днестра, 26 апреля 2016 Экология [Электронной ресурс]. Режим доступа: http://only-maps.ru/ekologiya/zagryaznenie-vody-v-bassejne-dnestra.

4. Справочник пестициды. Хлорорганические соединения (XОC) http://www.pesticidy.ru/ group_substances/organochlorines.

5. Ivanova, A., Wiberg, K., Ahrens, L., Zubcov, E., Dahlberg, A.-K., 2021. Spatial distribution of legacy pesticides in river sediment from the Republic of Moldova. Chemosphere 279, 130923. https://doi.org/10.1016/j.chemosphere.2021.130923.

6. Ivanova, A. Long-term residue of DDT compounds in surface sediments from the dniester River. In: Tendințe contemporane ale dezvoltării științei: viziuni ale tinerilor cercetători. Ediția 7 , Vol.1, 15 iunie 2018, Chişinău. Chișinău, Republica Moldova: Tipogr. „Biotehdesign”, 2018, p. 154-159. 